\title{
Numerical Simulation for Optimal Thickness Combination of CdS/ZnS Dual Buffer Layer CulnGaSe2 Solar Cell Using SCAPS 1D
}

\author{
T. Joseph Mebelson ${ }^{1, *}$ and K. Elampari ${ }^{2}$ \\ ${ }^{1}$ Research scholar, Reg. No. 17213152131009, Physics Research Centre, S. T. Hindu College, Nagercoil-2. \\ Affiliated to Manonmaniam Sundaranar University, Abishekapatti, \\ Tirunelveli - 627 012, Tamilnadu, India \\ ${ }^{2}$ Associate Professor, Department of Physics, S. T. Hindu College, Nagercoil-2. Affiliated to Manonmaniam \\ Sundaranar University, Abishekapatti, Tirunelveli - 627 012, Tamilnadu, India \\ mebelsonalex@gmail.com, elampari@rediffmail.com
}

\begin{abstract}
Background/objectives: The usage of Cadmium makes the solar cell very harmful to nature. In order to reduce the usage of Cadmium content in the dual buffer layered Copper-Indium-Gallium-Selenide (CIGS) solar cell, the buffer layer material properties could be tuned. Methods: The current-voltage behaviour of the CIGS solar cell is investigated on the effect of the buffer layer thickness combination by a numerical simulation using SCAPS 1D. Findings: The results indicate that the simulated model with a dual buffer layer shows higher efficiency compared to the individual CdS and ZnS single buffer layered solar cells. Applications: It is also found that $10 \mathrm{~nm} \mathrm{CdS}$ in combination with $50 \mathrm{~nm} \mathrm{ZnS}$ provides a maximum conversion efficiency of $25.149 \%$.
\end{abstract}

Keywords: Dual Buffer Layer, CIGS, SCAPS, Numerical Simulation.

\section{Introduction}

The Copper-Indium-Gallium-Selenide (CIGS) solar cell has received much attention in the photovoltaic (PV) industry when compared to the other conventional solar cell due to its desirable properties such as low production cost and flexibility. 1 The photon conversion efficiency (PCE) of CIGS solar cell has exceeded $22 \%$ in laboratory scale and $15 \%$ in commercial scale. ${ }^{2}-\underline{4}$ The incorporation of Sodium $(\mathrm{Na})$ content into the CIGS cell $\underline{\underline{5}}$ boosted its efficiency up to $22.6 \%$. The research regarding the highly efficient solar cell is digging every possibility to get better efficiency. The buffer layer, positioned beneath the window layer thus forming a P-N junction associated with the absorber layer used to reduce the recombination process $\underline{6}$ thus providing the band bending across the junction as large as possible. The energy gap should be wider for the buffer layer materials to allow more light to the CIGS absorber layer. For this purpose, a combination of different materials having a wider bandgap could be stacked to form a dual buffer layer.

Since the Cadmium (Cd) material used in the buffer layer of CIGS solar cell is noxious in nature, preferably it should be avoided or it should be abridged. Hence finding material on these aspects, for the buffer layer is in demand.

Therefore, the usage of CdS should be avoided or it should be reduced to develop an environmentally friendly solar cell. Though some of the materials such as $\mathrm{Zn}(\mathrm{O}, \mathrm{S})$, $\mathrm{ZnS}, \mathrm{ZnMgO}$ were employed as buffer layer materials instead of CdS, their performance was not comparable with CdS since these alternative buffers are more susceptible to the metastable effects such as light soaking and also the stability in damp heat testing is considerably low. $\underline{-}^{-} \underline{8}$ With this concern, the researchers put more interest in developing new technologies to achieve a good thin-film photovoltaic cell, especially on CIGS. Among the several buffer layer materials, $\mathrm{ZnS}$ shows a dynamic role since it

${ }^{*}$ Author for correspondence 
has a higher refractive index. This high refractive index of $\mathrm{ZnS}$ increases the photon absorption in the CIGS absorber layer and assists the solar cell to provide higher efficiency. $-\underline{-10}$ So as to produce a photovoltaic cell that is highly efficient and eco-friendly, two aspects come at this point; one is, using a buffer layer material with a wider bandgap in order to increase absorption of more light and the other is to reduce or avoid the cadmium content completely. For this purpose, the dual buffer layer can be adopted which promises a higher conversion efficiency.

Typically, in a dual buffer layer solar cell, another layer of material having a wider bandgap than the CdS, especially $\mathrm{ZnS}$ could be stacked in between the CdS and $\mathrm{ZnO}$ layers to overcome the low light absorption. This $\mathrm{CdS}: \mathrm{ZnS}$ setup is simulated by Oyedele et al and showed that the CIGS solar cell with CdS/ZnS buffer layer significantly produces high efficiency compared to the single buffer layer CIGS solar cells. 11 A theoretical view of buffer layer thickness emphasis that the higher the CdS thickness, the lower the power output. The thicker CdS layer leads to a decrease in efficiency. $\underline{12}$

Since there is no specific standard equation to calculate the buffer layer thickness composition of dual buffer layers, the simulation tools become very expedient to determine the desired thickness. Supporting this, many of the simulation software is available to investigate the performances of photovoltaic devices. $\frac{13}{-17}$ In this present work, a numerical simulation tool, a Solar Cell Capacitance Simulator (SCAPS 1D) is used to study the influence of the thickness composition of the CdS:ZnS dual buffer layers. The electrical behaviour of the CIGS solar cell has investigated and also the effective thickness composition ratio of the CdS:ZnS buffer layer is determined in this simulation study.

\section{Numerical Simulation}

The simulation software SCAPS 1D developed at the University of Ghent, Belgium, is used to simulate the CIGS solar cell. $\underline{18}$ The CIGS solar cell has the basic structure of CIGS/CdS/i-ZnO/ZnO:Al which is represented in Figure 1 . The parameter values of all the layers used in this simulation study are given in Table 1. The desirable thickness of buffer layer $\underline{19}$ endorsed by various studies is $50 \mathrm{~nm}$.

In this work, the thickness for both the single and dual buffer layer thickness was set to $60 \mathrm{~nm}$.

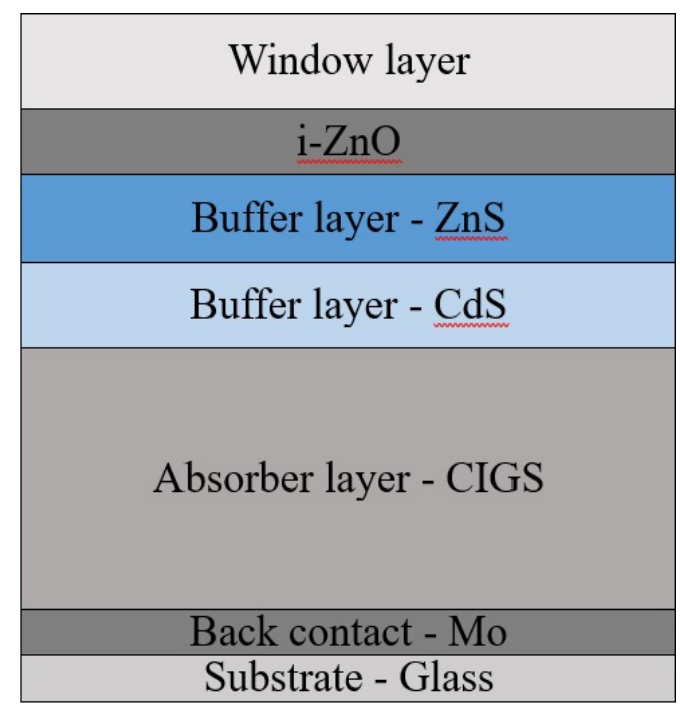

Figure 1. The schematic representation of CIGS solar cell with a dual buffer layer.

Table 1. The parameter values used for CIGS, CdS, ZnS and $\mathrm{ZnO}: \mathrm{Al}$ layers

\begin{tabular}{|c|c|c|c|c|}
\hline Parameter & CIGS & CdS & $\mathrm{ZnS}$ & ZnO:Al \\
\hline Thickness (nm) & 1900 & Variable & Variable & 200 \\
\hline Dielectric constant & 13.6 & 10 & 10 & 10 \\
\hline Band gap (eV) & 1.2 & 2.4 & 3.5 & 3.3 \\
\hline $\begin{array}{l}\text { Electron affinity } \\
(\mathrm{eV})\end{array}$ & 4.5 & 4.2 & 4.5 & 4.4 \\
\hline $\begin{array}{l}\text { CB density of states } \\
\left(\mathrm{cm}^{-3}\right)\end{array}$ & $\begin{array}{l}2.2 \times \\
10^{18} \\
\end{array}$ & $\begin{array}{l}2.2 \times \\
10^{18} \\
\end{array}$ & $\begin{array}{l}1.5 \times \\
10^{18} \\
\end{array}$ & $\begin{array}{l}2.2 \times \\
10^{18}\end{array}$ \\
\hline $\begin{array}{l}\text { VB density of states } \\
\left(\mathrm{cm}^{-3}\right)\end{array}$ & $\begin{array}{l}1.8 \times \\
10^{19}\end{array}$ & $\begin{array}{l}1.8 \times \\
10^{19}\end{array}$ & $\begin{array}{l}1.8 \times \\
10^{18}\end{array}$ & $\begin{array}{l}1.8 \times \\
10^{19}\end{array}$ \\
\hline $\begin{array}{l}\text { Electron mobility } \\
\left(\mathrm{cm}^{2} / \mathrm{V} \mathrm{s}\right)\end{array}$ & 25 & 5 & 50 & 100 \\
\hline $\begin{array}{l}\text { Hole mobility } \\
\left(\mathrm{cm}^{2} / \mathrm{V} \mathrm{s}\right)\end{array}$ & 10 & 5 & 20 & 25 \\
\hline $\begin{array}{l}\text { Electron thermal } \\
\text { velocity }(\mathrm{cm} / \mathrm{s})\end{array}$ & $\begin{array}{l}1 \times \\
10^{7}\end{array}$ & $1 \times 10^{7}$ & $1 \times 10^{7}$ & $1 \times 10^{7}$ \\
\hline $\begin{array}{l}\text { Hole thermal } \\
\text { velocity }(\mathrm{cm} / \mathrm{s})\end{array}$ & $\begin{array}{l}1 \times \\
10^{7}\end{array}$ & $1 \times 10^{7}$ & $1 \times 10^{7}$ & $1 \times 10^{7}$ \\
\hline
\end{tabular}

The simulation is carried out for single and dual buffer layered CIGS solar cells. The thickness combination of the buffer layers CdS:ZnS is regulated while maintaining the total buffer layer thickness at $60 \mathrm{~nm}$. The parameter values of CIGS, CdS and $\mathrm{ZnO}$ : Al layers used in this simulation study were taken from $\underline{20}$ and the parameter values of $\mathrm{ZnS}$ were adopted from. $\frac{19}{}$ 


\section{Result and Discussion}

There are many aspects that would possibly contribute to downgrading the overall performance of the photovoltaic cell. In this present work, the simulation is focused on the prime thickness combination of CdS: $\mathrm{ZnS}$ buffer layer. The solar spectrum file AM1.5G is simulated to initiate the solar spectrum in SCAPS 1D to study the optical and electrical behaviour of the CIGS solar cell.

\subsection{Influences of Single Buffer Layer}

Aiming to the electrical study, the current-voltage (I-V) behaviour respecting various thickness combinations of CdS:ZnS was analyzed. The tabulated values in Table 2 represent the results of the simulated study regarding the efficiency of the solar cell with respect to the other factors such as $\mathrm{V}_{\mathrm{oc}}, \mathrm{J}_{\mathrm{sc}}$ and fill factor.

From the tabulated results it is noted that the photon conversion efficiency of ZnS buffer layered CIGS solar cell is superior to that of the CdS buffer layered CIGS cell. This indicates that the $\mathrm{ZnS}$ has the prominent properties to hold as a worthy alternative of CdS. $\underline{21}$

\subsection{Influences of Dual Buffer Layer}

To create a dual buffer layered CIGS solar cell an additional buffer layer is added to the existing buffer layer. In this work $\mathrm{CdS}$ and $\mathrm{ZnS}$ materials are combined to construct a dual buffer layer. The CdS:ZnS buffer layer CIGS solar cell exhibits improved performance for all the characteristic values depending on the thickness combination involved. Figure 2 interprets the relation between $\mathrm{V}_{\mathrm{oc}}$ and CdS:ZnS thickness combination. It is observed that the $\mathrm{V}_{\mathrm{oc}}$ values slightly drops when the CdS thickness dominates. It doesn't show any notable variation for single and duallayered buffer layers. Since the variation is feeble it can be considered that the $\mathrm{V}_{\text {oc }}$ remains constant. This is in good agreement with the previous studies reported. $\underline{22}$

The variation in the $\mathrm{J}_{\mathrm{sc}}$ with respect to CdS:ZnS thickness combination is represented in Figure 3. The $\mathrm{J}_{\mathrm{sc}}$ value decreases considerably for the CdS:ZnS thickness

Table 2. The values of Voc, Jsc, FF and efficiency for $\mathrm{CdS}$ and $\mathrm{ZnS}$ buffer layers with thickness of $60 \mathrm{~nm}$

\begin{tabular}{|l|l|l|l|l|}
\hline Layer & $\mathbf{V}_{\text {oc }}(\mathbf{V})$ & $\mathbf{J}_{\text {sc }}\left(\mathbf{m A} / \mathbf{c m}^{2}\right)$ & FF (\%) & Eff (\%) \\
\hline ZnS & 0.87 & 35.28 & 74.84 & 23.05 \\
\hline CdS & 0.86 & 30.93 & 84.94 & 22.74 \\
\hline
\end{tabular}

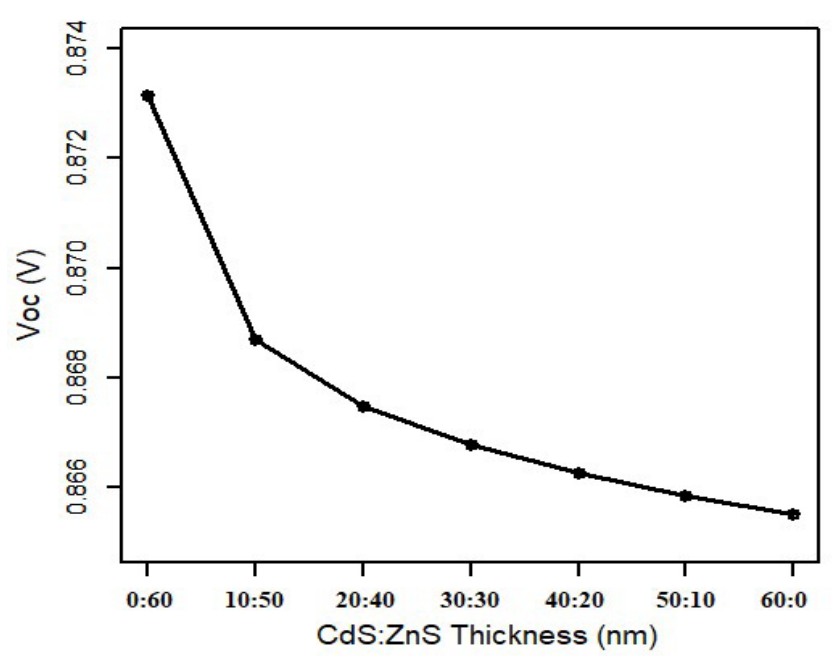

Figure 2. Graphical representation of Voc versus CdS:ZnS thickness combination

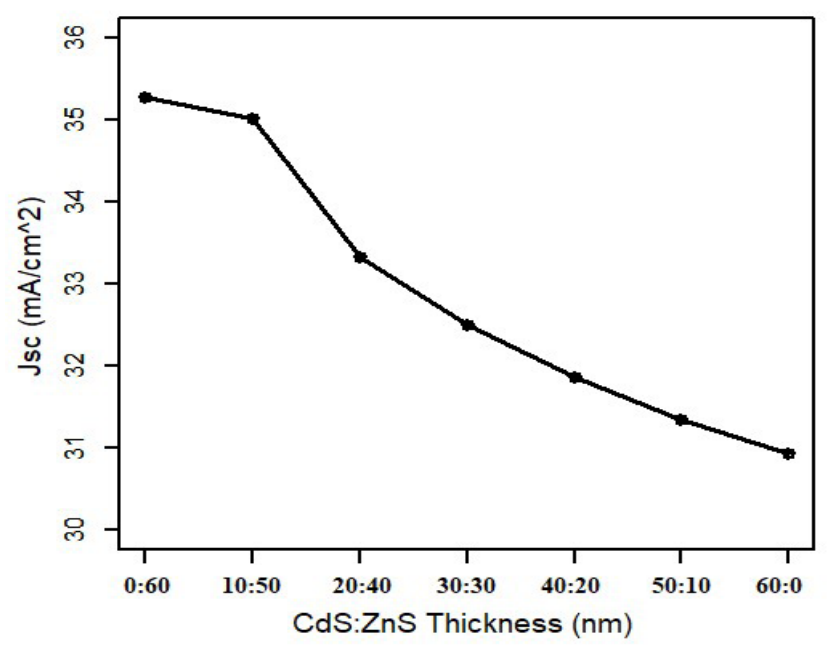

Figure 3. Graphical representation of Jsc for various thickness combinations of $\mathrm{CdS}: \mathrm{ZnS}$

combination 50:10 (nm). Besides, the 10:50 (nm) of CdS:ZnS combination exhibits higher $\mathrm{J}_{\text {sc }}$ value due to the photogenerated electron-hole pair with minimal absorption losses. This in response, absorbs more photons in the CIGS absorber layer. The recombination of charge carriers is also decreased since the minority carrier lifetime has improved due to the highly concentrated CdS layer. $\underline{23}$

Also, the thin layer of CdS buffer layer reduces the optical absorption losses which are the key factor for lower current at the junction.

Figure 4 represents how the CdS:ZnS thickness combination influence the fill factor of the PV cell. Figure 4 


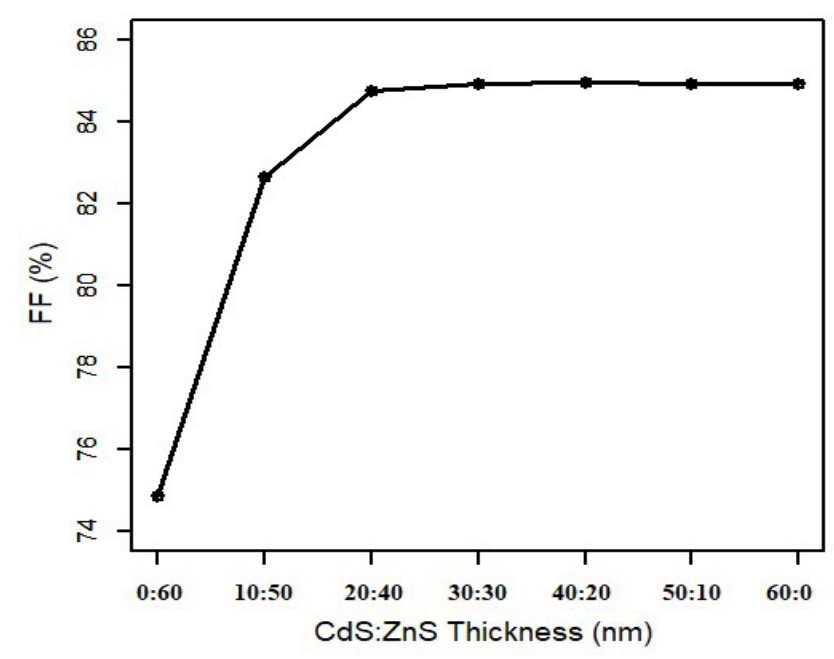

Figure 4. The plot of fill factor for various thickness combinations of CdS: ZnS.

shows that the fill factor value is lower for the $\mathrm{ZnS}$ buffer layer $(0: 60)$. The simultaneous variation in the thickness combination of CdS: $\mathrm{ZnS}$ influences the fill factor. Essentially the fill factor behaves directly proportional to the thickness of CdS layer and inversely proportional to that of $\mathrm{ZnS}$ layer. Simultaneous adjustment on the thickness of both buffer layers, confirms the maximum fill factor at 20:40 nm of CdS:ZnS thickness combination. In order to reduce the usage of Cadmium content the thickness combination of 10:50 nm for CdS: $Z n$ san be chosen as a desirable thickness combination of dual buffer layer.

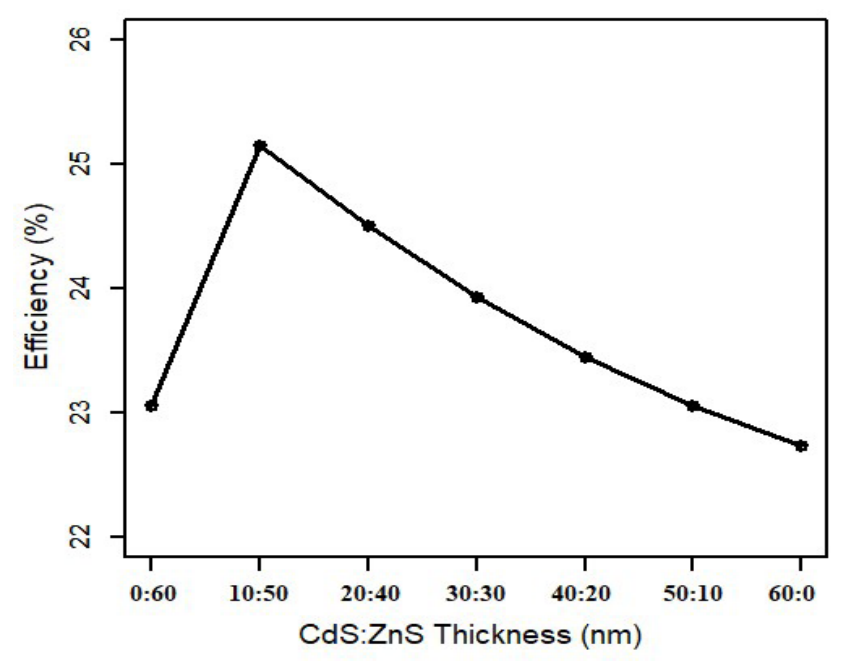

Figure 5. The plot representing the variation of efficiency versus $\mathrm{CdS}: \mathrm{ZnS}$ thickness combination
Figure 5 shows how the efficiency varies with respect to the CdS:ZnS thickness combination. When the buffer layer is of either $\mathrm{ZnS}$ or $\mathrm{CdS}$ as a single buffer layer with $60 \mathrm{~nm}$ of thickness, the photon conversion efficiency is relatively low compared to the dual buffer layered CIGS solar cell. By reducing the CdS layer thickness to 10 $\mathrm{nm}$ and maintaining the ZnS buffer layer as $50 \mathrm{~nm}$, the efficiency reaches the maximum level.

Even though the $\mathrm{V}_{\mathrm{oc}}$ and $\mathrm{J}_{\mathrm{sc}}$ of the $\mathrm{ZnS}$ single buffer layered CIGS PV cell is relatively higher than the other buffer layer combinations, the fill factor is relatively low for the $\mathrm{ZnS}$ buffer layer. Due to this reason the higher $\mathrm{V}_{\mathrm{oc}}$ and $\mathrm{J}_{\mathrm{sc}}$ values have no benefits in increasing the efficiency of the $\mathrm{ZnS}$ single buffered CIGS solar cells. Also, since the carrier density in the CdS buffer layer is greater than the $\mathrm{ZnS}$ buffer layer, the potential barrier of the heterojunctions increases which in response increases the space charge zone. It is evident that for the thinner layer of CdS, the carrier collection is high. $\frac{19}{}$ Due to this fact, there is a drop in conversion efficiency with increasing CdS thickness. Therefore, the thickness combination of 10:50 nm exhibits the enhanced PCE for CIGS PV cells.

The current-voltage behaviour of the simulated CIGS solar cell model is represented in Figure 6. The double buffer layered CIGS solar cell shows improved conversion efficiency than the single buffer layer solar cells due to the wider bandgap of $\mathrm{ZnS}$ and higher carrier collection of CdS. It can be seen that the knee region of the J-V characteristic of $\mathrm{ZnS}$ buffer layer shows a higher current decreasing ratio than the others. It implies that though

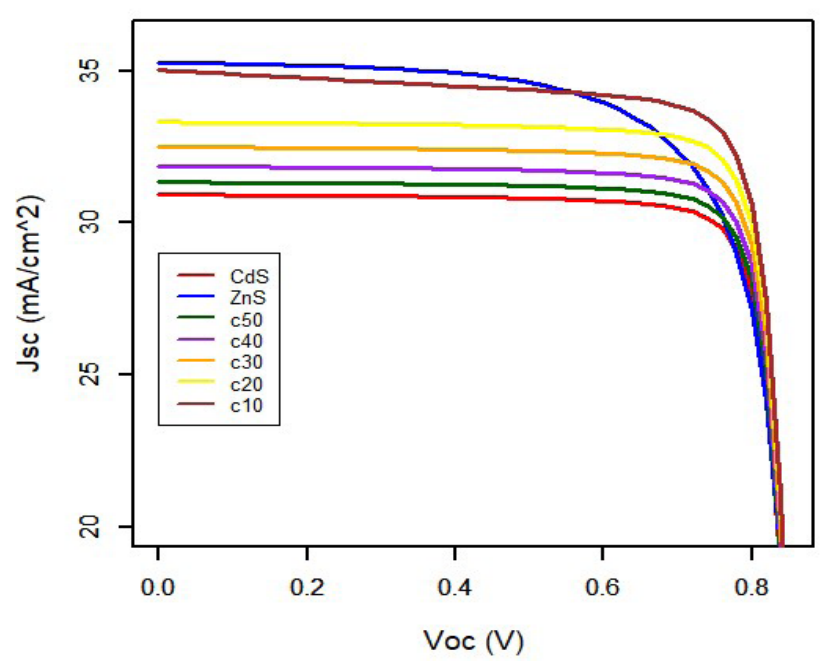

Figure 6. The J-V characteristics of single and double buffer layered CIGS solar cell. 
the wider bandgap of $\mathrm{ZnS}$ makes way for higher light absorption, the fill factor is relatively low which in turn decreases the efficiency.

From Figure 6 it can be seen that the addition of $\mathrm{CdS}$ with $\mathrm{ZnS}$ improves the squareness of the JV curves which means that the fill factor is also improved, hence the efficiency. It should be noted that the efficiency increases in spite of the small decrease in the fill factor after a 40:20 nm thickness combination. For the thickness combination, 10:50 nm of CdS:ZnS the $\mathrm{V}_{\text {oc }}$ and $\mathrm{J}_{\text {sc }}$ values are high, essential for the highly efficient solar cells.

\section{Conclusion}

The simulation is carried out to study the double buffer layered CIGS solar cell. At first CIGS cell is simulated with single buffer layers of CdS and ZnS materials. After that, a dual buffer layer with a combination of CdS/ZnS materials was used in this simulation study. It is found that the thickness combination of $40: 20 \mathrm{~nm}$ of CdS/ZnS shows a higher fill factor of about $84.9567 \%$. Regardless of its slightly lower fill factor, the CdS/ZnS thickness combination of 10:50 $\mathrm{nm}$ produces a higher conversion efficiency of $25.149 \%$.

\section{Acknowledgment}

The authors wish to thank Dr. Marc Burgelman, University of Gent, Belgium, for providing SCAPS 1D simulation software.

\section{References}

1. Kessler F, Rudmann D. Technological aspects of flexible CIGS solar cells and modules. Sol Energy. 2004;77:685-95.

2. Green MA, Hishikawa Y, Dunlop ED, Levi DH, HohlEbinger J, Ho-Baillie AWY. Solar cell efficiency tables (version 52). Prog Photovolt Res Appl. 2018;26:427-36.

3. Corson J, Austin A, Tas R, Mackie N, Larsson M, Demirkan $\mathrm{K}$, et al. Photovoltaic cell with high efficiency cigs absorber layer with low minority carrier lifetime and method of making thereof. 2018 Nov. US Patent App. 16/034,131.

4. Feurer T, Bissig B, Weiss TP, Carron R, Avancini E, Löckinger J, et al. Single-graded CIGS with narrow bandgap for tandem solar cells. Sci Technol Adv Mater. 2018;19:263-70.

5. Jackson P, Wuerz R, Hariskos D, Lotter E, Witte W, Powalla M. Effects of heavy alkali elements in $\mathrm{Cu}(\mathrm{In}, \mathrm{Ga}) \mathrm{Se} 2$ solar cells with efficiencies up to $22.6 \%$. Phys Status Solidi (RRL) Rapid Res Lett. 2016;10:583-6.

6. Ramli H, Rahim SKA, Rahman TD, Aminuddin MM. A numerical simulation on zinc sulfide (ZnS) buffer layer in CuInS2 based thin film solar cell. Chalcogenide Lett. 2013;10(9):341-8.

7. Nishinaga J, Kamikawa Y, Shibata H, Niki S. Dry heat testing under light irradiation of $\mathrm{Cu}(\mathrm{In}, \mathrm{Ga}) \mathrm{Se} 2$ solar cells. In: Grand renewable energy proceedings Japan council for renewable energy; 2018. P. 55.

8. Siebentritt S. Alternative buffers for chalcopyrite solar cells. Sol Energy. 2004;77:767-75.

9. Zhou L, Xue Y, Li J. Study on ZnS thin films prepared by chemical bath deposition. J Environ Sci. 2009;21:76-79.

10. Zhao Y, Zhong ES, Cho SJ. Kwon, Characterization of the $\mathrm{ZnS}$ thin film buffer layer for $\mathrm{Cu}(\mathrm{In}, \mathrm{Ga}) \mathrm{Se} 2$ solar cells deposited by chemical bath deposition process with different solution concentrations. Mater Chem Phys. 2012;135:287-92.

11. Oyedele SO, Aka B. Numerical simulation of varied buffer layer of solar cells based on cigs. Model Numer Simul Mater Sci. 2017;7:33.

12. Dabbabi S, Nasr TB, Kamoun-Turki N. Parameters optimization of CIGS solar cell using 2D physical modeling. Results Phys. 2017;7:4020-24.

13. Liu Y, Sun Y, Rockett A. A new simulation software of solar cells-wxAMPS. Sol Energy Mater Sol Cells. 2012;98:124-8.

14. Jiang Y, Qahouq JAA, Orabi M. Matlab/Pspice hybrid simulation modeling of solar PV cell/module. In: 2011 twenty-sixth annual IEEE applied power electronics conference and exposition (APEC); 2011. P. 1244-50.

15. Basore PA, Rover DT, Smith AW. PC-1D version 2: enhanced numerical solar cell modelling. In: Conference record of the twentieth IEEE photovoltaic specialists conference; 1988. P. 389-96.

16. Michael S, Bates AD, Green MS. Silvaco ATLAS as a solar cell modeling tool. In: Conference record of the thirty-first IEEE photovoltaic specialists conference; 2005. P. 719-21.

17. Mostefaoui M, Mazari H, Khelifi S, Bouraiou A, Dabou R. Simulation of high efficiency CIGS solar cells with SCAPS-1D software. Energy Procedia. 2015;74:736-44.

18. SCAPS manual. [cited $2013 \mathrm{Sep}$ ]. https://users.elis.ugent.be/ ELISgroups/solar/projects/scaps/SCAPS\%20Manual\%20 2\%20september\%202013.pdf.

19. Tousif MN, Mohammad S, Ferdous AA, Hoque MA. Investigation of different materials as buffer layer in CZTS solar cells using SCAPS. J Clean Energy Technol. 2018;6(4):293-6.

20. Nardone M, Patikirige Y, Walkons C, Bansal S, Friedlmeier TM, Kweon KE. Baseline models for three types of CIGS cells: effects of buffer layer and Na content. In: 2018 IEEE 7th world conference on photovoltaic energy conversion 
(WCPEC) (a joint conference of 45th IEEE PVSC, 28th PVSEC \& 34th EU PVSEC); 2018. P. 3013-18.

21. Bhattacharya RN, Ramanathan K. Cu(In,Ga)Se2 thin film solar cells with buffer layer alternative to CdS. Sol Energy. 2004;77:679-83.
22. Heriche H, Rouabah Z, Bouarissa N. High-efficiency CIGS solar cells with optimization of layers thickness and doping. Optik. 2016;127:11751-7.

23. Metzger WK, Repins IL, Contreras MA. Long lifetimes in high-efficiency $\mathrm{Cu}(\mathrm{In}, \mathrm{Ga}) \mathrm{Se} 2$ solar cells. Appl Phys Lett. 2008;93(2):022110-13. 